\title{
ROBERT KUPIECKI
}

Uniwersytet Warszawski

\section{Polskie sojusze 1918-2018. Teoria i doświadczenia}

\author{
Państwa szukają sity, bo bez niej maleje ich \\ bezpieczeństwo i szanse przetrwania, zdolność \\ odstraszania zagrożé, przekonywania innych \\ do pożądanego działania [...] bo [siła] zwiększa \\ liczbę opcji, a te podnosza bezpieczeństwo, \\ szanse rozwoju i spokój obywateli.
}

I. Cohen, Realpolitik. Theory and practice (1975)

\section{Polish alliances 1918-2018. Theory and experience}

The poor reputation of military alliances among Poles is the result of a shallow and indeed trivial understanding of the country's historical experience. In the realms of social perception and historical debate, Polish alliances are treated not as tools of foreign policy, which are strongly linked to the international context and interplay of interests between individual allies and actors that pose a threat to them, but as a universal solution to the country's security, which is to remain dependable regardless of circumstances. The aim of this article is to analyse experiences derived from twelve alliances entered by Poland between 1918 and 2018, in relation to the rationale for which they were formed, the methods and effects of their functioning, as well as the reasons for which eleven of them have been terminated. The theoretical underpinning of this analysis is the so-called general theory of international alliances that has been developed for the past couple of decades by numerous authors operating within the field of strategic studies, including Andrzej Dybczyński in Poland. The establishment of this kind of paradigm allows us to convincingly characterise this specific relationship between sovereign countries, as well as differentiate the alliances from other forms of international security cooperation. The knowledge available in this field is used in the analysis of alliances entered by Poland.

Keywords: international alliances, theory of alliances, NATO, Warsaw Pact

Słowa kluczowe: sojusze międzynarodowe, teoria sojuszy, NATO, Układ Warszawski 
Z pewnością żaden z instrumentów polityki bezpieczeństwa nie ma w Polsce gorszej reputacji aniżeli sojusze wojskowe. Brak zaufania do sojuszy jako takich tworzy jeden z najważniejszych narodowych stereotypów politycznych ostatniego stulecia. Na jego przeciwnym biegunie znajduje się z kolei traktowanie ich jako samoistnych gwarantów bezpieczeństwa. Obie te postawy są głęboko zakorzenione w świadomości społecznej ostatnich stu lat. Wizja Polski zawsze wiernej sojusznikom, obrazy entuzjazmu warszawskich tłumów wiwatujących 3 września 1939 r. na wieść o przystąpieniu Wielkiej Brytanii i Francji do wojny z Niemcami, propaganda niezłomnego Układu Warszawskiego czy traktowanie NATO jako bezwarunkowo bezpiecznej przystani dla Polski - to emocjonalne przejawy oceny polskich sojuszy w różnych okresach ich historii. Obserwacje te należałoby oczywiście konfrontować w szczegółach z kolejnymi związkami polityczno-wojskowymi zawieranymi przez polskie rządy. Choć wydają się one odpowiadać stanowi świadomości Polaków, to stanowią zlepek instynktów i emocji zbudowanych raczej na bolesnym bilansie tego, jakie nadzieje wiązano z sojuszami, czemu nie zapobiegły i jakich problemów nie rozwiązały, aniżeli poważnej refleksji strategicznej ${ }^{1}$. Ta wymaga bowiem rozumienia faktów, skutków, jakie one wywołują, twardego realizmu w ich ocenie oraz uporządkowanego, wolnego od przekonań zafałszowujących procesy myślowe podejścia do antycypacji zdarzeń, czyli swoistej kultury analitycznej. Sojusze są bowiem niczym więcej jak instrumentem polityki międzynarodowej i jako takie nie stanowią lekarstwa na wszystkie jej przypadłości. Nie niosą rytych w granicie gwarancji ważnych w każdych okolicznościach, nie unieważniają zasad stosunków międzynarodowych i gry narodowych interesów. Nie przypominają wreszcie instytucji charytatywnych ani też nie zdejmują z państw odpowiedzialności za zaniechania i dokonywane wybory².

1 Ramy analityczne w przedmiocie wzajemnych relacji celów, zachowania państw i skuteczności ich związków proponuje Amitai Etzioni: A. Etzioni, A comparative analysis of complex organizations. On power, involvement, and their correlates, New York 1975, zwłaszcza s. 103-152.

2 Bolesny wyłom w stereotypie sojuszników porzucających Polskę stanowią losy epizodycznego, choć kluczowego dla losów wojny z bolszewikami sojuszu polsko-ukraińskiego z lat 1919-1920. Wówczas to strona polska w dramatycznej dla siebie sytuacji podjęła decyzję o opuszczeniu sojusznika. Z kolei udział Wojska Polskiego w interwencji Układu Warszawskiego w Czechosłowacji w 1968 r. stanowił pogwałcenie nie tylko zasad prawa międzynarodowego, ale i podwójne naruszenie sojuszu, jaki wiązał Warszawę z Pragą dwustronnego i wielostronnego, obowiązującego w ramach układu. 
Weryfikacja wiarygodności sojuszy możliwa jest wyłącznie w chwili testu casus foederis: wiarygodne/niewiarygodne (skuteczne/nieskuteczne). Należy jednak pamiętać, że działają one w złożonym i dynamicznym kontekście zjawisk międzynarodowych, gdzie obok czynników wewnętrznych (budujących relacje państw członkowskich) zagrożenia zewnętrzne i konflikty zbrojne stanowią zaledwie część ich naturalnego środowiska. Każda z takich sytuacji podpowiada sojusznikom zazwyczaj zachowania racjonalne w kategoriach własnego bezpieczeństwa. Te zaś wymagają utrzymania możliwie dużej liczby opcji reagowania, gdzie zobowiązania międzynarodowe stanowią tylko jedną z przesłanek podejmowania decyzji - nie silniejszą wszelako od woli przetrwania, unikania strat czy opóźniania rozstrzygnięć do czasu wykorzystania wszystkich innych opcji. Warto przy tym pamiętać uwagę znawcy teorii tego zagadnienia, Andrzeja Dybczyńskiego: ,[...] trzy czwarte zawieranych sojuszy nie jest nigdy dotrzymywanych. W co dziesiątym aliansie

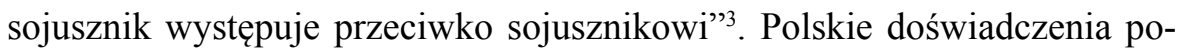
zwalają dodać do tej obserwacji sojusze, których utrzymywanie silniej zagraża egzystencji uczestników aniżeli ich brak ${ }^{4}$. Zdarzały się też takie, gdzie sposób wypełnienia zobowiązań nie zapobiegł wojnie i katastrofalnym skutkom dla polskiego państwa, społeczeństwa i narodu (w II RP). Może to sugerować, że dyktowany potrzebami suwerenny (zazwyczaj) wybór aliansów per se nie przesądzał o ich skuteczności albo że takie kryterium powinno być stosowane do szerszego zestawu sytuacji niż efektywna obrona przed agresją (np. redukcji zagrożeń, odstraszania agresji, wsparcia realizacji celów polityki zagranicznej w okresie pokoju, międzynarodowego wizerunku państwa).

Niewątpliwie w ostatnim stuleciu Polska wchodziła w związki sojusznicze z powodu słabości państwa, przede wszystkim w wymiarze militarnym na tle wschodniego i zachodniego sąsiedztwa, kiedy to potrzeba zapobiegania wybuchowi konfliktu lub redukcja zagrożenia stawały się wymogiem chwili. W okresie II RP i po 1989 r. wybór sojuszników był autonomiczną decyzją polskiej władzy centralnej. Inaczej wyglądało to w latach zimnej wojny - podejmowane wówczas decyzje rządu nie były funkcją suwerennego odczytania narodowych interesów Polski, ale realizacją woli obcego mocarstwa narzuconej państwom Europy Wschodniej.

3 A. Dybczyński, Sojusze międzynarodowe, Warszawa 2014, s. 12.

4 W ostatnim stuleciu, po zakończeniu drugiej wojny światowej Polska znajdowała się w takiej sytuacji przez niemal cztery dekady - mowa oczywiście o Układzie Warszawskim. 


\section{Polskie sojusze w perspektywie teoretycznej}

Badanie polskich sojuszy po 1918 r. nie jest rzeczą prostą przynajmniej z czterech powodów. Po pierwsze, naukowe analizy aliansów przyniosły już imponującą literaturę przedmiotu (głównie jednak zagraniczną), a także zbiór wiedzy o powodach ich zawiązywania i upadania oraz działaniu, niekoniecznie jednak spójny paradygmat poznawczy z niekwestionowanym aparatem pojęciowym. Należy wszak zgodzić się z wczesnym badaczem tego zjawiska, George'em Liską, że bez odwoływania się do sojuszy nie można mówić o stosunkach międzynarodowych, bo oba te pojęcia łączy wszystko poza nazwą ${ }^{6}$ Po drugie (także w przypadku aliansów zawieranych przez Polskę), mówimy o zjawisku jednorodnym tylko na poziomie ogólnej koncepcji, a silnie zróżnicowanym wewnętrznie, m.in. pod względem swobody wyboru sojuszników, stopnia suwerenności państwa w takich związkach, ich poziomu zinstytucjonalizowania, typów oraz celów (deklarowanych i rzeczywistych) czy wreszcie skuteczności, którą należałoby rozumieć jako racjonalny bilans stopnia wypełniania zobowiązań sojuszniczych i skutków, do jakich to doprowadziło. Ta ostatnia kwestia dodatkowo komplikuje zresztą perspektywę porównawczą, ponieważ nie wszystkie sojusze stanęły w obliczu sytuacji testowej. Po trzecie, badań nad sojuszami nie ułatwia zróżnicowanie faktycznej sytuacji politycznej Polski na przestrzeni ostatnich stu lat. II RP (1918-1945), Rzeczpospolita Polska / Polska Rzeczpospolita Ludowa (1945-1989) i III RP (po 1989 r.) to trzy formy ciągłości państwa polskiego, nieporównywalne jednak pod względem suwerenności i zdolności reagowania na rozpoznane zagrożenia narodowych interesów ${ }^{7}$. Samodzielność wyboru sojuszy międzynarodowych mających prowadzić do wzmocnienia bezpieczeństwa Polski była w tych okresach różna. Odmienny jest także bilans ich działalności, znaczenie mocarstwa hegemonicznego, formy organizacyjne (dwustronne i wielostronne), mechanizmy zarządzania tymi strukturami i polski wpływ na ich działanie. Po czwarte, szeroko

5 Pierwsze syntezy teorii sojuszy: A. Wolfers, Alliance policy in the Cold War, Baltimore 1959; G. Liska, Nations in alliance. The limits of interdependence, Baltimore 1962; R.E. Osgood, Alliances and American foreign policy, Baltimore 1968; O.R. Holsti, T.P. Hopmann, J.D. Sullivan, Unity and disintegration in international alliances, New York-London 1973; S.M. Walt, The origin of alliances, Ithaca-London 1987. Z polskich prac, obok cytowanej wyżej książki Andrzeja Dybczyńskiego (gdzie znajdziemy obszerny przegląd najnowszej literatury przedmiotu), zob. także: R. Kupiecki, NATO a operacje pokojowe. Studium sojuszu w transformacji, Warszawa-Toruń 1998, s. 15-63; B. Balcerowicz, Sity zbrojne w państwie i stosunkach międzynarodowych, Warszawa 2006, s. 72-90.

6 G. Liska, Nations..., s. 3.

7 Szerzej zob. R. Kupiecki, M. Madej, Bezpieczeństwo zbiorowe i kolektywna obrona w polskiej polityce bezpieczeństwa po 1918 r., „Stosunki Międzynarodowe” 2018, nr 1, s. 63-93. 
rozpowszechnione w społeczeństwie poczucie sojuszniczej zdrady z września 1939 r., wzmocnione jeszcze później doświadczeniem Jałty ${ }^{8}$, przyczyniło się do negatywnej oceny polskich sojuszy oraz nieufności wobec nich w przyszłości. Jest to jednak dość naiwna karykatura refleksji politycznej, bo choć psychologicznie zrozumiała, to jednak obciążająca narodową świadomość. Pozwala bowiem przerzucić odpowiedzialność za polskie porażki na czynniki zewnętrzne, zwalnia od refleksji nad własnym postępowaniem i nie służy edukacji strategicznej władzy i społeczeństwa.

Tabela 1. Związki sojusznicze Polski od 1918 r.

\begin{tabular}{|c|c|c|}
\hline $\begin{array}{c}\text { Okres } \\
\text { historyczny }\end{array}$ & Typy związków sojuszniczych & Bilans strategiczny \\
\hline $\begin{array}{l}\text { II RP } \\
(1918-1945)\end{array}$ & $\begin{array}{l}\text { Defensywne - równoważące } \\
\text { zagrożenie sojusze dwustronne } \\
\text { z Francją, Rumunią i Wielką } \\
\text { Brytanią oraz epizodyczny } \\
\text { ofensywno-defensywny sojusz } \\
\text { polsko-ukraiński; brak instytucjo- } \\
\text { nalizacji, autonomia decyzyjna } \\
\text { Polski }\end{array}$ & $\begin{array}{l}\text { Nieefektywne - wypełnienie } \\
\text { zobowiązań sojuszniczych nie } \\
\text { zapobiegło zniszczeniu państwa } \\
\text { i stratom wojennym, a w przypad- } \\
\text { ku sojuszu polsko-ukraińskiego } \\
\text { Polska w imię własnych interesów } \\
\text { porzuciła swoje zobowiązania }\end{array}$ \\
\hline $\begin{array}{l}\text { Rzeczpospolita } \\
\text { Polska / Polska } \\
\text { Rzeczpospo- } \\
\text { lita Ludowa } \\
\text { (1945-1989) }\end{array}$ & $\begin{array}{l}\text { Niesuwerenny hegemonistyczny } \\
\text { ofensywny sojusz wielostronny } \\
\text { Układu Warszawskiego z } 1955 \text { r.; } \\
\text { średnio wysoka instytucjonali- } \\
\text { zacja, narzucony podział zadań } \\
\text { wojskowych, brak wpływu Polski } \\
\text { na procesy zarządzania sojuszem, } \\
\text { marginalne znaczenie sojuszy } \\
\text { dwustronnych }\end{array}$ & $\begin{array}{l}\text { Utrzymanie równowagi sił w Euro- } \\
\text { pie - brak wojny i zagrożenia dla } \\
\text { Polski ze Wschodu, ale przez cały } \\
\text { okres trwania sojuszu wysokie } \\
\text { ryzyko uwikłania w wojnę nukle- } \\
\text { arną supermocarstw (w każdym } \\
\text { wariancie konfliktu obszar Polski } \\
\text { byłby teatrem działań wojennych); } \\
\text { podporządkowanie państwa stra- } \\
\text { tegii i planom wojennym ZSRR - } \\
\text { źródłem zagrożenia; brak alterna- } \\
\text { tyw w polityce bezpieczeństwa }\end{array}$ \\
\hline $\begin{array}{l}\text { III RP } \\
\text { (po 1989 r.) }\end{array}$ & $\begin{array}{l}\text { NATO - sojusz obronny z wy- } \\
\text { boru; wysoka instytucjonalizacja } \\
\text { i spójność, wpływ na procesy } \\
\text { decyzyjne, priorytet odstraszania } \\
\text { i kolektywnej obrony w ramach } \\
\text { szerszych misji sojuszu (zarządza- } \\
\text { nie kryzysowe, polityka partner- } \\
\text { stwa), hegemoniczna pozycja } \\
\text { USA buforowana wewnętrznie } \\
\text { poprzez sposób podejmowania } \\
\text { decyzji i zewnętrzne procesy } \\
\text { integracji europejskiej }\end{array}$ & $\begin{array}{l}\text { Względnie niskie ryzyko wybuchu } \\
\text { wojny angażującej Polskę - mocne } \\
\text { gwarancje bezpieczeństwa, sku- } \\
\text { teczna polityka odstraszania, brak } \\
\text { źródeł konfliktu z innymi państwa- } \\
\text { mi NATO, istotne źródła wyzwań } \\
\text { w otoczeniu międzynarodowym }\end{array}$ \\
\hline
\end{tabular}

Źródło: oprac. własne

8 Odosobnione w polskiej literaturze naukowej spojrzenie na międzynarodowy kontekst decyzji konferencji w Jałcie, oparte na wolnej od emocji analizie zachowań i motywacji jej uczestników, zob. K. Kersten, Jałta w polskiej perspektywie, Londyn 1989. 
Historia sojuszy (w ich nowożytnej inkarnacji badanej od czasu pokoju westfalskiego), przyczyny ich powstawania i rozpadu, sposób funkcjonowania oraz wpływ na otoczenie to ważne czynniki rozwoju współczesnych stosunków międzynarodowych ${ }^{9}$. W praktyce sojuszami zwykło się nazywać związki państw o różnym charakterze:

- ententy - zobowiązania o luźniejszym charakterze politycznym;

- koalicje - przejściowe formy współpracy służące osiągnięciu wspólnie wskazanych celów;

- układy - wyraz oczekiwań dotyczących zachowań partnerów w stosunkach międzynarodowych;

- reżimy - zbiory norm, reguł i procedur służące osiąganiu celów zewnętrznych, ale już niekoniecznie stawiające podobne cele wewnątrz takiej formuły współpracy międzynarodowej ${ }^{10}$.

Polska w ostatnim stuleciu wielokrotnie występowała jako strona takich form współpracy w dziedzinie bezpieczeństwa, np.:

- jako członek Wielkiej Koalicji antyhitlerowskiej w drugiej wojnie światowej czy koalicji antyirackich podczas obu wojen Zatoce Perskiej;

- w całym omawianym okresie w bardzo licznych układach międzynarodowych, dających niekiedy przesłanki pozwalające traktować je jako związki sojusznicze (nie zawsze jednak tak było, o czym świadczą np. polsko-sowiecki pakt o nieagresji z $1932 \mathrm{r}^{11}{ }^{11}$, polsko-niemiecka deklaracja o niestosowaniu przemocy z 1934 r. $^{12}$ czy też tzw. układ Sikorski-Majski z 1941 r. i późniejsze porozumienie wojskowe ${ }^{13}$ );

- jako uczestnik reżimów, np. w zakresie ochrony praw człowieka, rozbrojenia, nieproliferacji broni masowego rażenia czy kontroli eksportu ${ }^{14}$.

W praktyce mogą one jednak nie być sojuszami, a tylko formą prowadzonych przez nie działań. Alianse pojawiają się dopiero w momencie, gdy

9 Próba ujęcia stanu wiedzy na temat tych aspektów sojuszy w spójną teorię: A. Dybczyński, Sojusze..., s. 120-285 (rozdz. 3-5).

10 Rozważania terminologiczne zob. tamże, s. 91-100. Obok wspomnianych wyżej terminów dla pojęcia sojusz autor ten wskazuje również synonimy: alians, blok, przymierze, pakt.

11 Pakt nieagresji między Rzeczapospolitą Polska a Zwiąkiem Socjalistycznych Republik Rad, podpisany w Moskwie dnia 25 lipca 1932 roku, Dz.U. 1932, nr 115, poz. 951. Dokument ten przedłużony został tzw. Protokołem moskiewskim z 5 maja 1934 r., Dz.U. 1935, nr 53, poz. 487.

12 Deklaracja między Polska a Niemcami o niestosowaniu przemocy, podpisana w Berlinie dnia 26 stycznia 1934 roku, Dz.U. 1934, nr 16, poz. 124.

13 Teksty w: Układ Sikorski-Majski. Wybór dokumentów, red. E. Duraczyński, Warszawa 1990.

14 Notabene kwestia ta $\mathrm{w}$ odniesieniu do polskiej polityki zagranicznej zasługiwałaby na odrębne i systematyczne badania prowadzone zgodnie $\mathrm{z}$ rygorem teoretycznym i terminologicznym. W ramach tego ostatniego doprecyzowania wymagałyby np. różnice i wzajemne zależności między reżimami a układami międzynarodowymi. 
zachodzi sformalizowane lub nie porozumienie dwóch lub więcej państw prowadzące do (jednostronnego lub wzajemnego) powstania zobowiązania do udzielenia pomocy zbrojnej w określonych sytuacjach - charakteryzujące wyłącznie sojusze ${ }^{15}$. Sam sojusz zatem nie jest w sensie politycznym i prawnym kategorią ścisłą, o czym zdają się świadczyć liczne definicje, jakie przynosi literatura przedmiotu. Słusznie zatem Andrzej Dybczyński, wychodząc poza ich ograniczenia i wiedzę płynącą z komparatystyki ${ }^{16}$, próbuje definiować sojusze poprzez zespół wyróżniających je cech:

1. Są związkami suwerennych aktorów międzynarodowych (zdolnych generować potencjał obronny).

2. Sumują potencjały obronne państw członkowskich i mają mechanizmy wspólnego zarządzania.

3. Odzwierciedlają wspólnotę sojuszniczych interesów.

4. Są zorientowane na przyszłe bezpieczeństwo (antycypacja rozwoju wydarzeń).

5. Zakładają wywiązywanie się stron ze zobowiązań sojuszniczych (gwarancje bezpieczeństwa).

6. Są reakcją na istnienie określonego przeciwnika, nie zawsze otwarcie nazwanego.

7. W ich ramach zachodzi współpraca militarna państw członkowskich.

8. Wspólnym sojuszniczym celem jest utrzymanie status quo.

9. Występuje wzajemność zobowiązań sojuszniczych ${ }^{17}$.

Wszystkie te cechy, z różnymi niuansami, odnajdziemy w charakterystyce polskich związków sojuszniczych ostatniego stulecia. W latach 1918-2018 Polska związana była 12 formalnymi sojuszami, z czego 4 przypadły na czasy II Rzeczypospolitej, 7 - na okres po 1944 r. i 1 - na III RP. Tylko 2 spośród nich miały charakter wielostronny; reszta to sojusze dwustronne. Z wyjątkiem efemerycznego sojuszu z Ukrainą u progu polskiej niepodległości w $1920 \mathrm{r}$., z Wielką Brytanią w 1939 r. i Jugosławią w latach 1946-1949 związki sojusznicze Warszawy cechuje długie trwanie. Wypełniały one niemal cały okres dwudziestolecia międzywojennego (sojusze z Francją i Rumunią - 18 lat); zimnej wojny (najdłuższy był sojusz dwustronny z ZSRR, który trwał ponad 45 lat, najkrótszy zaś z Niemiecką Republiką Demokratyczną - 32 lata). Wielostronny alians państw komunistycznych - Układ Warszawski istniał przez 36 lat, a członkiem Organizacji Traktatu Północnoatlantyckiego Polska jest od 1999 r., czyli 20 lat.

15 Szerzej zob. R. Kupiecki, NATO a operacje..., s. 21-30.

16 A. Dybczyński, Sojusze..., s. 56-67.

17 Tamże, s. 67-83. Autor twierdzi, że czynniki 1-5 występują we wszystkich sojuszach, a 6-9-w większości znanych $\mathrm{z}$ historii. 
We wszystkich sojuszach, w których funkcjonowała Polska, niezależnie od okresu wskazany był w sposób jawny lub tajny (w latach międzywojennych) konkretny przeciwnik. Do wybuchu drugiej wojny światowej były nim Niemcy (alians z Francją) oraz Związek Sowiecki (sojusz polsko-rumuński). W latach zimnej wojny sojusze państw obozu komunistycznego, ukrywając częściowo swoje zamiary w dokumentach założycielskich, zwrócone były przeciwko Niemcom Zachodnim, USA i blokowi państw NATO. Gdy Polska przystępowała w 1999 r. do Paktu Północnoatlantyckiego, nie wskazywał on oficjalnie swego przeciwnika, a niejawne dokumenty planistyczne odnosiły się do szerokiego spektrum zagrożeń zarówno o charakterze terytorialnym, jak i związanych z działalnością państw. Wraz z agresją Rosji na Ukrainę powrócono w NATO do oficjalnej ekspozycji zagrożenia ze strony Moskwy.

Każdy z polskich sojuszy ostatniego stulecia obejmował silny komponent współpracy wojskowej - słabo zorganizowanej w latach II RP, za to ściśle koordynowanej (kontrolowanej przez Moskwę) we wszystkich rozwiązaniach sojuszniczych po 1945 r. Każdy też charakteryzowała wzajemność zobowiązań państw członkowskich oraz oczekiwanie ich wypełniania. Sojusze międzywojenne w świetle zapisów traktatowych zrealizowano na minimalnym poziomie, a w perspektywie polskich oczekiwań nie zostały one wypełnionew obliczu agresji niemieckiej Polska nie otrzymała czynnej pomocy wojskowej. Zważywszy na marginalne znaczenie powojennych sojuszy dwustronnych, oba związki wielostronne, których członkiem była Polska, zakładały wywiązywanie się przez sygnatariuszy z ich zobowiązań, ale nie oznaczało to równości wkładu do wspólnej organizacji. Zarówno jednak w przypadku Układu Warszawskiego (Ludowe Wojsko Polskie jako druga po ZSRR armia bloku komunistycznego), jak i NATO sojuszniczy wkład Warszawy był znaczący.

Interesująco $\mathrm{w}$ tej perspektywie rysuje się kryterium sojuszniczego celu, wskazane wyżej jako utrzymanie status quo. O ile można tak opisać cele polskich sojuszy międzywojennych (utrzymanie pokoju na Wschodzie i Zachodzie oraz ochrona powersalskich granic), o tyle określenie elementów status quo w późniejszym czasie nie wydaje się już tak jednoznaczne. Dotyczy to zwłaszcza lat zimnej wojny, gdzie mógł być to zaledwie jeden z celów (defensywny) Układu Warszawskiego, będącego przecież instrumentem sowieckiej strategii ofensywnej ${ }^{18}$. Jego najważniejszym założeniem było przecież rewidowanie wszelkimi sposobami sytuacji w Europie na korzyść państw

18 Interesującym pytaniem badawczym w świetle teorii sojuszy jawi się kwestia, czy Układ Warszawski w ogóle spełnia kryteria definicyjne tego rodzaju związku państw. Dotyczy to np. rzeczywistej suwerenności sygnatariuszy w podejmowaniu decyzji o stowarzyszeniu, a później wpływu na jego działalność czy wreszcie istnienia realnej wspólnoty ich interesów. 
komunistycznych. Pokój i równowaga sił w tej perspektywie rysują się zaledwie jako elementy taktyki bloku komunistycznego, a nie cel jego działań ${ }^{19}$. Podobnie istotą planów NATO po zakończeniu zimnej wojny nie było przecież konserwowanie starych podziałów w Europie, ale ułożenie zasad współpracy międzynarodowej na nowo. Polska po przystąpieniu do organizacji stała się najpierw beneficjentem, a potem współwykonawcą strategii partnerstwa, którą uczyniono jednym $\mathrm{z}$ trzech filarów koncepcji strategicznej sojuszu ${ }^{20}$.

Z formalnych znamion sojuszy wskazanych przez Dybczyńskiego wszystkich tego rodzaju związków z udziałem Polski dotyczyły następujące: partnerami były inne, nominalnie suwerenne państwa; zakładano wzajemne uzupełnianie i wzmacnianie sojuszniczych potencjałów obronnych; deklarowano wspólnotę interesów; kierowano uwagę ku minimalizacji przyszłych zagrożeń.

Tabela 2. Sojusze Polski w latach 1918-2018

\begin{tabular}{|l|l|l|}
\hline Okres & \multicolumn{1}{|c|}{ Oryginalna podstawa prawna } & \multicolumn{1}{c|}{ Typ sojuszu } \\
\hline \multirow{4}{*}{ II RP } & $\begin{array}{l}\text { Konwencja wojskowa między przedstawicielami } \\
\text { Ministerstwa Spraw Wojskowych RP a Rzadem } \\
\text { Ukraińskiej Republiki Ludowej (24 kwietnia 1920 r.) })^{21}\end{array}$ & $\begin{array}{l}\text { sformalizowany, } \\
\text { ofensywno-obronny }\end{array}$ \\
\cline { 2 - 3 } & $\begin{array}{l}\text { Umowa francusko-polska (19 lutego 1921 r. })^{22} \\
\text { Konwencja o przymierzu odpornem między Rzeczapospo- } \\
\text { lita Polska a Królestwem Rumunii (3 marca 1921 r. })^{23}\end{array}$ & sformalizowany, obronny \\
\cline { 2 - 3 } & $\begin{array}{l}\text { Uktad o pomocy wzajemnej między Rzeczpospolita } \\
\text { Polska a Zjednoczonym Królestwem Wielkiej Brytanii } \\
\text { i Irlandii Pótnocnej (25 sierpnia 1939 r. })^{24}\end{array}$ & sformalizowany, obronny \\
\hline
\end{tabular}

19 Szerzej na temat sowieckich planów zob. R. Kupiecki, Siła i solidarność. Strategia NATO 1949-1989, Warszawa 2012, s. 268-273.

20 Bilans tej polityki wobec Rosji zob. Stosunki NATO-Federacja Rosyjska w świetle dokumentów, red. R. Kupiecki, M. Menkiszak, Warszawa 2018.

21 Źródło: Dokumenty i materiały do historii stosunków polsko-radzieckich, t. 2, red. N. Gąsiorowska-Grabowska, Warszawa 1961, s. 749-753. Konwencję wojskową poprzedzała konwencja polityczna z 21.04.1920 r. Zob. tamże, s. 745-747. Wcześniejszą formą układu o charakterze sojuszniczym była Umowa między delegatem Ukraińskiej Republiki Ludowej Borysem Kurdynowskim a Prezesem Rady Ministrów RP Ignacym Paderewskim w sprawie udzielenia pomocy wojskowej rzadowi ukraińskiemu dla walki z Ukraina Radziecką. Zob. tamże, s. 259.

22 Dz.U. 1922, nr 63, poz. 563. Porozumienie dopełniała tajna konwencja wojskowa z 21.02.1921 r. Warunki sojuszu zostały doprecyzowane na mocy Traktatu Gwarancyjnego pomiędzy Polska a Francja, podpisanego w Londynie dnia 1 grudnia 1925 r. Zob. Dz.U. 1926, nr 22, poz. 131. Zob. także Protokół końcowy francusko-polskich rozmów sztabowych 15-17 maja 1939, „Bellona” (Londyn) 1958, z. 2, s. 176-177.

23 Dz.U. 1921, nr 81, poz. 557. Podstawa prawna sojuszu polsko-rumuńskiego była dwukrotnie aktualizowana mocą traktatów gwarancyjnych z 26.03.1925 r. (Dz.U. 1927, nr 16, poz. 117) oraz 15.01.1931 r. (Dz.U. 1931, nr 32, poz. 230).

24 Tekst wraz z tajnym protokołem za: H. Batowski, Agonia pokoju i poczatek wojny, Poznań 1979, s. 182-185. 


\begin{tabular}{|c|c|c|}
\hline Okres & Oryginalna podstawa prawna & Typ sojuszu \\
\hline \multirow{8}{*}{$\begin{array}{l}\text { RP/ } \\
\text { PRL }\end{array}$} & $\begin{array}{l}\text { Uktad o przyjaźni, pomocy wzajemnej i wspótpracy } \\
\text { powojennej polsko-radzieckiej (21 kwietnia } 1945 \text { r. })^{25}\end{array}$ & $\begin{array}{l}\text { sformalizowany, } \\
\text { ofensywno-obronny }\end{array}$ \\
\hline & $\begin{array}{l}\text { Układ o przyjaźni i pomocy wzajemnej między } \\
\text { Rzeczpospolita Polska i Federacyjna Republikg } \\
\text { Jugostawii (18 marca } 1946 \text { r. })^{26}\end{array}$ & sformalizowany, obronny \\
\hline & $\begin{array}{l}\text { Układ o przyjaźni i wzajemnej pomocy między Polska } \\
\text { a Czechostowacja }(10 \text { marca } 1947 \text { r. })^{27}\end{array}$ & $\begin{array}{l}\text { sformalizowany, } \\
\text { ofensywno-obronny }\end{array}$ \\
\hline & $\begin{array}{l}\text { Uktad o przyjaźni, wspótpracy i wzajemnej pomocy } \\
\text { między Polska a Butgaria (29 maja } 1948 \text { r. })^{28}\end{array}$ & $\begin{array}{l}\text { sformalizowany, } \\
\text { ofensywno-obronny }\end{array}$ \\
\hline & $\begin{array}{l}\text { Układ o przyjaźni, wspótpracy i wzajemnej pomocy } \\
\text { między Polska a Węgrami (18 czerwca } 1948 \text { r. })^{29}\end{array}$ & $\begin{array}{l}\text { sformalizowany, } \\
\text { ofensywno-obronny }\end{array}$ \\
\hline & $\begin{array}{l}\text { Polsko-rumuński pakt przyjaźni, wspótpracy } \\
\text { i wzajemnej pomocy (26 stycznia } 1949 \text { r.) }{ }^{30}\end{array}$ & $\begin{array}{l}\text { sformalizowany, } \\
\text { ofensywno-obronny }\end{array}$ \\
\hline & $\begin{array}{l}\text { Układ o przyjaźni, wspótpracy i pomocy wzajemnej } \\
(15 \text { maja } 1955 \mathrm{r} .)^{31}\end{array}$ & $\begin{array}{l}\text { wielostronny, } \\
\text { sformalizowany, } \\
\text { ofensywno-obronny }\end{array}$ \\
\hline & $\begin{array}{l}\text { Układ o przyjaźni, wspólpracy i wzajemnej pomocy } \\
\text { zawarty między Polska Rzeczpospolita Ludowa a Nie- } \\
\text { miecka Republika Demokratyczna (15 marca } 1967 \text { r.) }\end{array}$ & $\begin{array}{l}\text { sformalizowany, } \\
\text { ofensywno-obronny }\end{array}$ \\
\hline III RP & $\begin{array}{l}\text { Traktat Pólnocnoatlantycki sporzadzony } \\
\text { w Waszyngtonie dnia } 4 \text { kwietnia } 1949 r^{13}\end{array}$ & $\begin{array}{l}\text { wielostronny, } \\
\text { sformalizowany, obronny }\end{array}$ \\
\hline
\end{tabular}

Źródło: oprac. własne

25 „Zbiór Dokumentów” 1945, nr 2, s. 51-54. Nową podstawę prawną sojusz ten otrzymał mocą podpisanego 8.04.1946 r. Układu o przyjaźni, wspótpracy i wzajemnej pomocy między PRL a ZSRR. Zob. „Zbiór Dokumentów” 1965, nr 4, s. 369-374.

26 „Zbiór Dokumentów” 1946, nr 3, s. 70-72. Sojusz obowiązywał do 1949 r.

27 „Zbiór Dokumentów” 1947, nr 3, s. 105-108. Odnowiona podstawa prawna z 1.03.1967 r.: Układ o przyjaźni, wspótpracy i wzajemnej pomocy między Polska Rzeczpospolita Ludowa a Czechostowacka Republika Socjalistyczna, „Zbiór Dokumentów” 1967, nr 3, s. 293-298.

28 „Zbiór Dokumentów” 1948, nr 6, s. 299-302. Odnowiona podstawa prawna z 6.04.1967 r.: Układ o przyjaźni, wspótpracy $i$ wzajemnej pomocy zawarty między Polska Rzeczpospolita Ludowa a Ludową Republika Bułgarii, „Zbiór Dokumentów” 1967, nr 4-5, s. 448-454.

29 „Zbiór Dokumentów” 1948, nr 6, s. 302-305. Odnowiona podstawa prawna z 16.05.1968 r.: Układ zawarty między Polską a Węrami o przyjaźni, wspótpracy i pomocy wzajemnej, „Zbiór Dokumentów” 1968, nr 5, s. 557-562.

30 „Zbiór Dokumentów” 1949, nr 2, s. 91-95. Odnowiona podstawa prawna z 12.11.1970 r.: Układ między Polska Rzeczpospolita Ludowa a Socjalistyczna republika Rumunii o przyjaźni, wspótpracy i wzajemnej pomocy, „Zbiór Dokumentów” 1970, nr 11, s. 1853-1858.

31 „Zbiór Dokumentów” 1955, nr 5, s. 908-918. Układ Warszawski pierwotnie zawarty został na 20 lat, ale w 1975 r. przedłużono go na kolejne 10, a w 1985 - dalsze 20 lat. Formalne rozwiązanie układu nastąpiło 1.07.1991 r.

32 „Zbiór Dokumentów” 1967, nr 3, s. 299-306.

33 Dz.U. 2000, nr 87, poz. 970. Polska przystąpiła do Organizacji Traktatu Północnoatlantyckiego $12.03 .1999 \mathrm{r}$. 
Niedostatki siły własnej państwa polskiego, ograniczenia zdolności szybkiego rozwinięcia jego potencjału obronnego oraz wysokie koszty zapewnienia bezpieczeństwa stanowiły główny motyw poszukiwania przez Warszawę wzmocnienia $\mathrm{z}$ zewnątrz w postaci związków sojuszniczych. Dotyczyło to każdej sytuacji w czasach II i III RP, gdy polskie rządy mogły podejmować w polityce zagranicznej samodzielne decyzje. Zwłaszcza w ostatnim okresie tendencję tę podkreśla poszukiwanie związków z NATO i gotowość do spełnienia trudnych warunków członkostwa ${ }^{34}$. Po 1945 r. państwo polskie, świadome możliwych kosztów politycznej niesubordynacji, musiało przyjąć narzucone mu siłą związki. Otwarte pozostaje natomiast pytanie, jak silna była świadomość politycznych i wojskowych elit PRL odnośnie do skali zagrożeń wynikających z trwania w sojuszu nierespektującym narodowych interesów Polski i czyniącym z niej przedmiot w strategicznej rozgrywce supermocarstw. Być może snop światła na tę kwestię rzuca przypadek Ryszarda Kuklińskiego.

Nieostro w kontekście powodów wchodzenia przez Polskę w związki sojusznicze rysują się natomiast różnice między wskazywanymi przez teoretyków sojuszy strategiami ofensywnego lub defensywnego przylączania i równoważenia. Jeśli bowiem istotą pierwszej jest budowanie związków z państwem silniejszym (w oczekiwaniu korzyści lub minimalizacji szkód), a drugiej - ograniczenie zagrożenia ze strony większych państw, to w decyzjach polskich władz dotyczących wyboru sojuszników widoczne są obie te motywacje, silnie przemieszane. Nie dotyczy to oczywiście sytuacji powojennej, w której Polska, jako członek Układu Warszawskiego, była zarówno ofiarą, jak i narzędziem sowieckiego hegemonizmu, ponieważ obiektywnie wspierała realizowanie go w Europie Wschodniej. Trudno przecież uznać zawieranie dwustronnych sojuszy położonych blisko siebie państw komunistycznych za realizację strategii równoważenia potęgi Moskwy. Ich bilateralne relacje nie pełniły także roli generatora sił $\mathrm{w}$ lokalnej rywalizacji z blokiem państw zachodnich. Udziałem Polski było wówczas sześć takich związków, jednak były one czysto symboliczne, gdyż nie realizowały nawet swojej systemowej roli redukcji ryzyka wzajemnych konfliktów - tę pełniła bowiem sowiecka regulacja i kontrola. W pozostałych okresach w sojuszach z udziałem Polski można odnaleźć motywy równoważenia i przyłączania, przy czym te z czasów II RP wydają się ułomnie równoważyć zagrożenia i potencjał potęg europejskich,

34 R. Kupiecki, Atlanticism in post-1989 Polish foreign policy, [w:] Poland's security policy 1989-2000, ed. R. Kuźniar, Warsaw 2001, s. 229-285. 
natomiast członkostwo w NATO jest klasycznym przypadkiem równoważenia zagrożenia ze Wschodu poprzez związanie się z sojuszem państw zachodnich.

Wyjąwszy okres PRL, kluczowym problemem Polski zawsze było ryzyko porzucenia przez sojuszników, osamotnienia lub rozpadu organizacji, której była członkiem, pod wpływem zmieniających się okoliczności międzynarodowych. Wizja utknięcia w szarej strefie bezpieczeństwa motywowała Warszawę do wysiłku politycznego i wojskowego przez dekadę starań o akcesję do NATO. Główną troską II RP było z kolei niedopuszczenie do rozmycia sojuszniczych zobowiązań wobec niej oraz wzmacniania bezpieczeństwa Europy Zachodniej kosztem państw wschodnioeuropejskich. Mniejsze znaczenie od ryzyka bycia porzuconym miało dla Polski uwikłanie w konflikty innych sojuszników. Realny problem stanowił tu właściwie jedynie Układ Warszawski, ponieważ brak zdolności realnego wpływania na jego decyzje i polityczna kontrola (penetracja) ZSRR podnosiły prawdopodobieństwo zaistnienia takich scenariuszy, choć oczywiście nie gwarantowały Moskwie subordynacji państw satelickich w chwili próby ${ }^{35}$.

Ocenę przyczyn rozpadu sojuszy z udziałem Polski ułatwia fakt, że 11 na 12 (z wyjątkiem NATO) należy już do przeszłości. Przyczyny kresu aliansów II RP miały charakter zewnętrzny. Wybuch drugiej wojny światowej, agresja przeciw Polsce przeprowadzona $\mathrm{z}$ dwóch stron przez Niemcy i ZSRR, okupacja terytorium państwa oraz sposób wypełnienia zobowiązań sojuszniczych przez jej aliantów istotnie zmieniły sytuację. Zniknął bowiem kontekst terytorialny zobowiązań, rząd RP udał się na emigrację, a dawni sojusznicy Rzeczypospolitej stanęli przed zagrożeniami wymagającymi innej alokacji posiadanych zasobów. $Z$ ich perspektywy sprawa polska zeszła na dalszy plan.

Przyczyny rozpadu aliansów PRL były bardziej złożone, wiązały się bowiem zarówno z sytuacją wewnętrzną państw członkowskich, sytuacją wewnątrz sojuszu, jak również zaistnieniem nowych okoliczności międzynarodowych. Co więcej, wszystkie te trzy czynniki zadziałały równocześnie, zakończenie zimnej wojny oznaczało bowiem powstanie zasadniczo odmiennej sytuacji - zanik zagrożenia nagłą agresją i wojną totalną. Poprawa sytuacji zwiększyła liczbę opcji bezpieczeństwa państw po obu stronach dawnej żelaznej kurtyny. Postępujący rozkład potęgi ZSRR (niezdolnego już do kontrolowania swych sojuszników/satelitów) oznaczał dysfunkcję dawnego mocarstwa

35 Badanie tego problemu stanowiło jedno z najważniejszych zadań analitycznych NATO przez cały czas trwania zimnej wojny, co ukazują coraz szerzej dostępne archiwa sojuszu, a także amerykańskie archiwalia udostępniane w ramach programu CREST. 
hegemonicznego w Układzie Warszawskim ${ }^{36}$. Mogło ono tylko wycofywać się $\mathrm{z}$ dawnych pozycji w imperium zewnętrznym, ułatwiając przeprowadzenie zmian na jego obszarze. Reorientacja jednych i powstanie innych, nowych państw w sąsiedztwie Polski unieważniły istniejące dotychczas dwustronne porozumienia sojusznicze. Nowa sytuacja oznaczała transformację systemu politycznego w Polsce, wymianę i kooptację elit oraz fundamentalną redefinicję interesów narodowych, strategii polityki zagranicznej i związków sojuszniczych wyrażającej się w coraz wyraźniejszym od początku lat dziewięćdziesiątych XX w. powrocie na Zachód. Członkostwo w NATO postawiło zaś przed Polską nowe sojusznicze wyzwania, odmienne od historycznych doświadczeń państwa w tej mierze.

\section{Polskie sojusze - spojrzenie wstecz $^{37}$}

Mit założycielski II RP głosił, że odzyskanie niepodległości umożliwił własny wysiłek zbrojny, a nie uwarunkowania zewnętrzne i obce mocarstwa. W takiej optyce sojusze dwustronne miały wspierać zakorzenienie młodego państwa w polityce europejskiej, redukować jego słabość i nie ograniczać swobody decyzyjnej w polityce zagranicznej. Nie było w tym sprzeczności, a cele polityki bezpieczeństwa Polski wzajemnie się nie wykluczały, zwłaszcza w odniesieniu do III Rzeszy i Związku Sowieckiego - potężniejszych od swojego wspólnego sąsiada $^{38}$. Dopóki więc alianse nie musiały być weryfikowane w oparciu o $\mathrm{ca}$ sus foederis, państwo polskie nie stawało wobec zagrożeń egzystencjalnych. Epizodyczne, funkcjonujące w latach wojny $\mathrm{z}$ bolszewikami i walk o granice krótkotrwałe układy polityczno-wojskowe z Łotwą (1919), Ukrainą $(1919,1920)$ i państwami bałtyckimi (Estonią, Litwą, Łotwą i Finlandią - 1920) świadczyły o samotności strategicznej Polski i jej ograniczonej atrakcyjności jako potencjalnego koalicjanta. Pokazuje to także niezdolność do stworzenia wielostronnego sojuszu angażującego państwa regionu. Realne opcje sojusznicze przez większość okresu międzywojennego zawęziły się więc do Francji i Rumunii.

Sojusz z Francją - pierwszą potęgą na kontynencie - istniał nieprzerwanie od 1921 r. i przynosił zobowiązanie do wzajemnej pomocy na wypadek

36 Szerzej zob. J.M. Nowak, Od hegemonii do agonii. Upadek Układu Warszawskiego. Polska perspektywa, Warszawa 2011.

37 Obszerniej na temat tych zagadnień zob. R. Kupiecki, M. Madej, Bezpieczeństwo..., s. 63-93.

38 M. Kornat, Polityka równowagi 1934-1939. Polska między Wschodem a Zachodem, Kraków 2007. 
agresji niemieckiej. Jako taki stanowił niemały sukces dyplomatyczny młodego państwa, ale z drugiej strony różnice potencjałów i zapatrywań obu partnerów na kwestie polityki europejskiej skazywały go na duże wahania intensywności współpracy. Zależność Warszawy od wsparcia wojskowego Paryża pozwalała mu na elastyczne zarządzanie własnymi zobowiązaniami wobec sojusznika $^{39}$. O ile alians z Francją dawał poczucie bezpieczeństwa Polski na Zachodzie, o tyle na Wschodzie rolę taką pełnił funkcjonujący od $1921 \mathrm{r}$. sojusz z Rumunią. Choć bezalternatywny na tym kierunku, w przeciwieństwie do związku z potęgą francuską sumował on raczej gospodarcze i militarne słabości obu państw.

Od wczesnych lat trzydziestych świadoma rosnącego zagrożenia ze strony Niemiec Polska zabiegała o zbliżenie z Wielką Brytanią. Ostatecznie do zawarcia sojuszu doszło pięć dni przed wybuchem drugiej wojny światowej, z inicjatywy brytyjskiej. Niezdolność, ale i brak woli Zjednoczonego Królestwa oraz sojuszniczej Francji do efektywnego udzielenia napadniętej Polsce pomocy militarnej ${ }^{40}$ podkreśla tyleż pustkę tego spóźnionego gestu politycznego, co nadmiar nadziei pokładanych przez Warszawę w sojuszach. 3 września 1939 r. Francja i Wielka Brytania wypowiedziały wprawdzie III Rzeszy wojnę, podnosząc do rangi światowej lokalny dotąd konflikt polsko-niemiecki, ale nie udzieliły broniącej się Rzeczypospolitej czynnej pomocy wojskowej. Zawarte w okresie międzywojennym związki sojusznicze pozwoliły złapać oddech polskiej polityce zagranicznej, lecz ich praktyczne znaczenie okazało się ograniczone - nie były zdolne obronić pokoju, powstrzymać Adolfa Hitlera i Józefa Stalina ani uratować niepodległości Polski. W jakimś sensie kres międzywojennych sojuszy Rzeczypospolitej stanowił zapowiedź kolejnych czterech dekad jej niesuwerennego funkcjonowania w układzie międzynarodowym.

Po 1944 r. państwa zachodnie odmówiły uznania polskiemu rządowi w Londynie, wobec czego kontynuacja dawnych związków wojennych była nierealna. Polska znalazła się w strefie sowieckiej dominacji, a nowe opcje sojusznicze zostały jej narzucone. Przesunięte na zachód państwo wyniszczone sześcioletnią wojną i okupacją, uszczuplone ludnościowo i terytorialnie sprowadzone zostało do pozycji formalnie suwerennej, ale bez zdolności decydowania o własnej polityce. Wobec zimnowojennej rywalizacji Moskwy i Waszyngtonu oraz krystalizacji dwóch bloków polityczno-wojskowych PRL

39 Szerzej zob. J. Ciałowicz, Polsko-francuski sojusz wojskowy 1921-1939, Warszawa 1970.

40 W. Dobrzycki, Historia stosunków międzynarodowych 1815-1945, Warszawa 2003, s. $469-470$. 
stawała się państwem frontowym, położonym na przedpolu możliwego konfliktu militarnego (konwencjonalnego i nuklearnego). W sensie wojskowym była częścią ofensywnych planów Układu Warszawskiego i jego ważnym zapleczem strategicznym. W warunkach wojny supermocarstw zniszczenie Polski - na niewyobrażalną skalę - byłoby przesądzone. Taki konflikt mógłby oznaczać kres jej egzystencji.

PRL była członkiem jednego sojuszu wielostronnego - Układu Warszawskiego, wraz z ZSRR, Czechosłowacją, NRD, Węgrami, Bułgarią, Rumunią i Albanią (do 1968 r.). W istocie jednak pierwotną intencją Moskwy nie było budowanie trwałego sojuszu wojskowego ze swymi kontrolowanymi przecież w pełni satelitami. ZSRR podjął prace nad stworzeniem własnego związku dopiero po odrzuceniu przez NATO w 1954 r. jego aplikacji członkowskiej (mającej na celu rozłożenie paktu od środka) oraz fiasku sowieckich inicjatyw obustronnego rozwiązania sojuszy na Wschodzie i Zachodzie oraz szeregu propozycji związanych z bezpieczeństwem zbiorowym (wspieranych przez Polskę) $)^{41}$. Procedury decyzyjne UW i jego strukturę cechowała jednak fasadowość, a wpływ satelitów na planowanie i decyzje był co najwyżej marginalny. Sztab Zjednoczonych Sił Zbrojnych UW powołano dopiero w 1969 r., a ich statut przyjęto dziesięć lat później, czyli ćwierć wieku po powstaniu organizacji ${ }^{42}$. Okazała się więc ona karykaturą sojuszu, gdzie współpraca polityczna i konsultacje nie miały praktycznego znaczenia, siły zbrojne członków były podporządkowane operacyjnie dowództwu Armii Radzieckiej ${ }^{43}$, a ich struktury decyzyjne kontrolowane przez Moskwę. Wbrew deklaracjom zapisanym w podstawie prawnej UW był porozumieniem ofensywnym, mającym wykorzystać potencjał państw satelickich ZSRR w razie konfliktu z NATO. Status nominalnej drugiej siły militarnej układu ${ }^{44}$ nie przekładał się na pozycję Polski w procesach wewnątrzsojuszniczych.

W latach 1945-1949, a więc jeszcze przed utworzeniem Układu Warszawskiego, Polska zawarła odrębne porozumienia sojusznicze z sześcioma

41 Szerzej zob. R. Kupiecki, Siła..., s. 28-29, 271-272.

42 Wcześniej rolę tę pełnił X Zarząd Sztabu Generalnego Armii Radzieckiej z akredytowanymi przy nim oficerami łącznikowymi armii państw satelickich. Szerzej zob. R. Kałużny, Uktad Warszawski 1955-1991, „Zeszyty Naukowe WSOWL” 2008, nr 1, s. 190-191.

43 A cardboard castle? An inside history of the Warsaw Pact 1955-1991, ed. V. Mastny, M. Byrne, Budapest-New York 2005.

44 Stwierdzało to w swoich dokumentach również NATO. Szerzej zob. R. Kupiecki, NATO wobec wydarzeń Października 1956 roku w Polsce, [w:] Polski Październik 1956 w polityce światowej, red. J. Rowiński Warszawa 2006, s. 278. Zob. także A. Paczkowski, Wojsko Polskie w Układzie Warszawskim. Od marzeń o polskim froncie do rzeczywistości stanu wojennego, „Zeszyty Historyczne” 2007, nr 161, s. 146-162. 
państwami komunistycznymi ${ }^{45}$. Po powstaniu UW ich znaczenie zmalało, a formalne odnowienie tworzących je traktatów w latach 1965-1970 (w związku z wygaśnięciem poprzednich umów) stanowiło już tylko podkreślenie trwałości sowieckiej dominacji nad państwami satelickimi. Trudno doszukiwać się w nich suwerennych prób zwiększenia autonomii względem Moskwy, ponieważ role państw satelickich były przez nią ściśle rozpisane oraz nadzorowane i nieczęsto pojawiało się w traktatach miejsce na działania własne, interpretowane zresztą jako blokowa niesubordynacja.

Rozpad bloku wschodniego w 1989 r., a wkrótce także ZSRR, umożliwił Polsce odrzucenie statusu satelickiego i prowadzenie suwerennej polityki stopniowego zbliżania się z Zachodem i jego instytucjami bezpieczeństwa. Wychodząca z politycznej zależności od Moskwy Polska należała do inicjatorów rozwiązania Układu Warszawskiego, co ostatecznie nastąpiło w lipcu 1991 r. Zmiany realizowano jednak stopniowo, bez prowokowania ZSRR, który utrzymywał swoje wojska na polskim terytorium aż do 1993 r., i w poczuciu niegotowości Zachodu do przedstawienia szybkiej oferty integracyjnej nowym demokracjom na wschodzie Europy ${ }^{46}$. Oznaczało to jednak powstanie w Europie Środkowej próżni bezpieczeństwa, otoczonej z jednej strony przez stabilny Zachód, a z drugiej przez neoimperialną Rosję będącą sukcesorką ZSRR. W Polsce problem ten postanowiono rozwiązać poprzez integrację ze strukturami zachodnimi, w tym z NATO. Jakkolwiek u źródeł tej decyzji leżała chęć przynależności do sojuszu gwarantującego zbiorową obronę, to jednak był to także wybór cywilizacyjny Polski, związany z poczuciem przynależności do wspólnoty zachodnich demokracji.

Członkostwo w NATO było początkowo głównym celem strategicznym polskiej polityki zagranicznej, a po przystąpieniu do organizacji stało się centralnym czynnikiem jej bezpieczeństwa ${ }^{47}$. Takie miejsce Sojuszu Północnoatlantyckiego w polskiej polityce bezpieczeństwa potwierdzają kolejne edycje Strategii bezpieczeństwa narodowego $R P^{48}$. Status sojuszniczy wywierał wpływ nie tylko na polską myśl strategiczną, ale także na kierunek i zakres programów rozwoju sił zbrojnych oraz stosowne procedury planistyczne. Od chwili akcesji do sojuszu Polska opowiadała się za prymatem

45 Szerzej zob. J. Tyranowski, Traktaty sojusznicze Polski Ludowej, Warszawa 1972.

46 Zob. K. Skubiszewski, Polityka zagraniczna i odzyskanie niepodległości. Przemówienia, oświadczenia, wywiady 1989-1993, Warszawa 1997.

47 Szerzej zob. R. Kupiecki, NATO u progu XXI wieku, Warszawa 2000, s. 9-153.

48 Szerzej zob. Strategia bezpieczeństwa narodowego RP. Pierwsze 25 lat, red. R. Kupiecki, Warszawa 2015. 
kolektywnej obrony wśród jego zadań. Jeszcze przed pierwszym rozszerzeniem organizacji w 1999 r. przyjęto jednak ograniczenia w kwestii rozmieszczenia wojsk oraz infrastruktury sojuszniczej na terytoriach nowych członków, co skutkowało odsłonięciem wschodniej flanki NATO, niedysponującej rozwiązaniami typowymi dla jego zachodniej części. Odwracanie tej sytuacji rozpoczęło się wskutek decyzji podjętych na szczycie w Newport w 2014 r. Stałym elementem działań Polski w NATO były też zabiegi o zwiększenie obecności USA w Europie. W takiej perspektywie należy widzieć polsko-amerykańską dwustronną współpracę wojskową. Jest ona tym istotniejsza, im silniejsze są za Atlantykiem głosy nawołujące do rewizji związków transatlantyckich. Sojusz Północnoatlantycki ma dla Polski znaczenie centralne jako formuła kolektywnej obrony, gwarancja bezpieczeństwa i mnożnik własnych wysiłków obronnych ${ }^{49}$.

\section{Zamiast zakończenia - spojrzenie w przyszłość}

Tempo i nieprzewidywalność zmian zachodzących w sferze bezpieczeństwa międzynarodowego stawiają przed polską polityką wyzwania ciągłej oceny jakości związków sojuszniczych i pracy na rzecz ich umacniania. Być może bowiem okres pozimnowojennej pauzy strategicznej oraz sojuszniczego komfortu uwalniającego od podejmowania trudnych decyzji i wybaczającego błędy minął bezpowrotnie pod presją zagrożeń na Wschodzie i Południu oraz zasadniczej transformacji, jakiej podlegają systemy wewnętrzne państw Zachodu. W tej ostatniej kwestii pojawiają się też wyraźne pytania o skutki, jakie będzie miała dla NATO nowa amerykańska polityka - America first. Deklaruje ona transakcyjność relacji transatlantyckich i wyrównywanie symetrii korzyści wynikających z utrzymywania wspólnego sojuszu. W ocenie Donalda Trumpa powinny one faworyzować USA jako państwo ponoszące największe obciążenia na rzecz Paktu Północnoatlantyckiego i mającego w nim największe wpływy. W praktyce jednak Waszyngton utrzymuje jak dotąd tradycyjne podejście, tzn. gwarancje USA dla europejskich sojuszników.

Dla Polski sam fakt istnienia sojuszu (podzielonego wewnętrznie co do oceny zagrożeń i kierunków działań) może mieć istotne znaczenie, jeżeli chodzi o bieżące cele polityki zagranicznej. Jako zasób strategiczny państwa na trudne czasy wymaga jednak stałej weryfikacji wiarygodności istniejących rozwiązań, zabiegów o wzmocnienie zdolności do realizacji

49 R. Kupiecki, Organizacja Traktatu Pótnocnoatlantyckiego, Warszawa 2014, s. 158-202. 
zaciągniętych zobowiązań i przemyślanych działań własnych w tym kierunku. To ostatnie wymaga politycznej rozwagi w wyborze sposobów utrzymywania relacji sojuszniczych, programowania rozwoju własnej potęgi jako efektu sojuszniczej synergii, a nie strategicznego ubezwłasnowolnienia państwa. Jeśli bowiem na jednym biegunie sojuszniczych ryzyk mieści się osamotnienie Polski, to na przeciwległym leżą zobowiązania zaciągane na wyrost - nieprzemyślane i nieumacniające obrony narodowej. Jedne i drugie prowadzą do sytuacji bezalternatywnych, czyli w efekcie powrotu do tego, co było przekleństwem Polski przez ostatnie sto lat.

Nie musi być to samospełniająca się przepowiednia, ale nowa sytuacja wymaga poważnej refleksji. Strategiczne przesłanki utrzymywania przez Polskę związków sojuszniczych nie ulegają zmianie. Składają się na nie deficyt potęgi własnej i niekorzystny układ sił w najbliższym otoczeniu. Cytowany wcześniej Andrzej Dybczyński wskazuje na szerszy zestaw czynników obciążających zdolność wypracowania przez Polskę nowoczesnej strategii sojuszniczej. Jego zdaniem należą do nich:

- brak utrwalonej kultury strategicznej,

- wynikające z geopolityki względnie wąskie pole manewru dla skutecznej polityki bezpieczeństwa (Zachód albo Rosja),

- niezrozumienie czy po prostu niski poziom edukacji strategicznej społeczeństwa i jego elit,

- wreszcie brak systematyczności w analizie doświadczeń sojuszniczych współczesnego świata jako niedostatek orientacji strategicznej ${ }^{50}$.

Jakkolwiek z ujęciem zagadnień na tej liście można by dyskutować (np. czy rzeczywiście problemem Polski jest brak dość trudnej w konceptualizacji i operacjonalizacji kultury strategicznej), to z wyjątkiem obiektywnej sytuacji geopolitycznej trzy pozostałe czynniki możliwe są do przezwyciężenia. Wymaga to jednak m.in. systematycznej pracy państwowej, świadomie prowadzonej edukacji budującej zdolności wyciągania poprawnych wniosków z przeszłości, uznanie strategii za pożyteczny czynnik wspierający prowadzenie polityki bezpieczeństwa oraz troski o kapitał ludzki - grono strategów państwowych. Kształcenie tych ostatnich trwa długo, a pożytek z ich wykorzystywania przez państwo jest niezaprzeczalny. Refleksja o tych sprawach to jednak temat na odrębną publikację.

50 A. Dybczyński, Dwutorowa asymetria. Sojusze Rzeczypospolitej w XXI w., „Polski Przegląd Dyplomatyczny" 2017, nr 2. 


\section{Bibliografia}

Balcerowicz B., Sity zbrojne w państwie i stosunkach międzynarodowych, Warszawa 2006. Batowski H., Agonia pokoju i początek wojny, Poznań 1979.

A cardboard castle? An inside history of the Warsaw Pact 1955-1991, ed. V. Mastny, M. Byrne, Budapest-New York 2005.

Ciałowicz J., Polsko-francuski sojusz wojskowy 1921-1939, Warszawa 1970.

Deklaracja między Polska a Niemcami o niestosowaniu przemocy, podpisana w Berlinie dnia 26 stycznia 1934 roku, Dz.U. 1934, nr 16, poz. 124.

Dobrzycki W., Historia stosunków międzynarodowych 1815-1945, Warszawa 2003.

Dokumenty i materiaty do historii stosunków polsko-radzieckich, t. 2, red. N. Gąsiorowska-Grabowska, Warszawa 1961.

Dybczyński A., Dwutorowa asymetria. Sojusze Rzeczypospolitej w XXI w., „Polski Przegląd Dyplomatyczny" 2017, nr 2.

Dybczyński A., Sojusze międzynarodowe, Warszawa 2014.

Etzioni A., A comparative analysis of complex organizations. On power, involvement, and their correlates, New York 1975.

Holsti O.R., Hopmann T.P., Sullivan J.D., Unity and disintegration in international alliances, New York-London 1973.

Kałużny R., Układ Warszawski 1955-1991, „Zeszyty Naukowe WSOWL”2008, nr 1.

Kersten K., Jalta w polskiej perspektywie, Londyn 1989.

Kornat M., Polityka równowagi 1934-1939. Polska między Wschodem a Zachodem, Kraków 2007.

Kupiecki R., Atlanticism in post-1989 Polish foreign policy, [w:] Poland's security policy 1989-2000, ed. R. Kuźniar, Warsaw 2001.

Kupiecki R., NATO a operacje pokojowe. Studium sojuszu w transformacji, Warszawa-Torun 1998.

Kupiecki R., NATO u progu XXI wieku, Warszawa 2000.

Kupiecki R., NATO wobec wydarzeń Października 1956 roku w Polsce, [w:] Polski Październik 1956 w polityce światowej, red. J. Rowiński, Warszawa 2006.

Kupiecki R., Organizacja Traktatu Pótnocnoatlantyckiego, Warszawa 2014.

Kupiecki R., Siła i solidarność. Strategia NATO 1949-1989, Warszawa 2012.

Kupiecki R., Madej M., Bezpieczeństwo zbiorowe i kolektywna obrona w polskiej polityce bezpieczeństwa po 1918 r., „Stosunki Międzynarodowe” 2018, $\mathrm{nr} 1$.

Liska G., Nations in alliance. The limits of interdependence, Baltimore 1962.

Nowak J.M., Od hegemonii do agonii. Upadek Układu Warszawskiego. Polska perspektywa, Warszawa 2011.

Osgood R.E., Alliances and american foreign policy, Baltimore 1968.

Paczkowski A., Wojsko Polskie w Układzie Warszawskim. Od marzeń o polskim froncie do rzeczywistości stanu wojennego, „Zeszyty Historyczne” 2007, nr 161.

Pakt nieagresji między Rzeczapospolita Polska a Zwiąkiem Socjalistycznych Republik Rad, podpisany w Moskwie dnia 25 lipca 1932 roku, Dz.U. 1932, nr 115, poz. 951.

Poland's security policy 1989-2000, ed. R. Kuźniar, Warsaw 2001.

Polski Październik 1956 w polityce światowej, red. J. Rowiński, Warszawa 2006.

Protokót końcowy francusko-polskich rozmów sztabowych 15-17 maja 1939, „Bellona” (Londyn) 1958, z. 2.

Skubiszewski K., Polityka zagraniczna i odzyskanie niepodległości. Przemówienia, oświadczenia, wywiady 1989-1993, Warszawa 1997. 